\title{
Higher Civil Servants in the Russian Ministry of Internal Affairs: Some Demographic and Career Characteristics, 1905-1916
}

One of those organs of tsarist government that apparently broadened its responsibilities and competencies during the nineteenth century was the Ministry of Internal Affairs (MVD). ${ }^{1}$ At the turn of the century the Ministry's authority extended over political and civil police, local agrarian affairs, licensing of physicians and veterinarians, gathering of statistical data for the empire (including censuses), postal and telegraphic services, press licensing and censorship, civil engineering, as well as other, equally diverse, areas. The publicly announced rationale for this vast range of competencies was that these functions all were directly related to the public welfare. As a government document written for Western consumption in the 1890s put it, the Ministry was "allotted the very extensive task of caring for the universal welfare of the people, the peace, quiet, and good order of the whole Empire."2

Given the apparent significance of this arm of tsarist domestic administration, it seems useful to ask whether its personnel had certain professional characteristics and educational qualifications in common and, if so, whether these characteristics were appropriate ones in light of the operational concerns of the organization. Looked at across a span of years, this information should be useful in identifying coherent patterns of change or stability, and it should consequently be of use to those interested in studying the interaction between a large public bureaucracy and its social, economic, and political environments.

1. (Ministerstvo Vnutrennikh Del). Numerous works are available which deal with the structure and operation of the tsarist bureaucracy in the early twentieth century. Citations to most of these are found in Erik Amburger, Geschichte der Behördenorganisation Russlands von Peter dem Grossen bis 1917 (Leiden, 1966) ; N. P. Eroshkin, Istoriia gosudarstzennykh uchrezhdenii dorevoliutsionnoi Rossii, 2nd rev, ed. (Moscow, 1968); and my "Study of the Imperial Ministry of Internal Affairs in the Light of Organization Theory" in Roger E. Kanet, ed., The Behavioral Revolution and Communist Studies (New York, 1971), pp. 209-31. Works that deal centrally with the MVD are somewhat rarer. Useful ones include Leonid Dashkevich, Nashe Ministerstvo Vnutrennikh Del (Berlin, 1895) ; Ministerstvo Vuutrennikh Del: Istoricheskii ocherk (St. Petersburg, 1901); the memoirs of the former high MVD official, V. I. Gurko, Featurcs and Figures of the Past: Government and Opinion in the Reign of Nicholas II (Stanford, 1939); and the bibliography by Edward Ellis Smith and Rudolf Lednicky, "The Okhrana": The Russian Department of Police (Stanford, 1967).

2. The Statesman's Handbook for Riussia, 2 vols. (St. Petersburg, 1896), 1:397. 


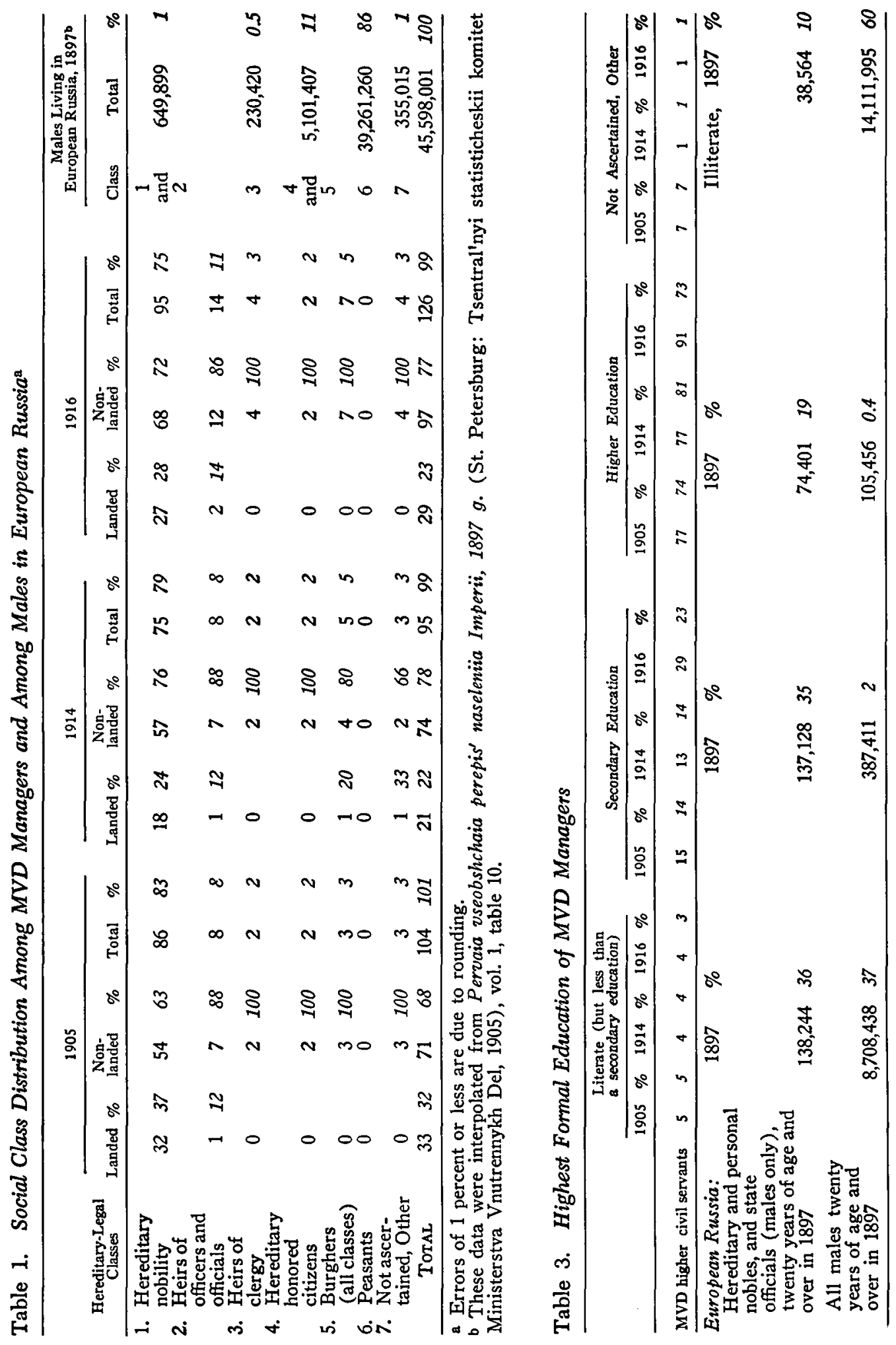


Table 2. Religious Affliation of MVD Managers

\begin{tabular}{|c|c|c|c|c|c|c|c|c|}
\hline Religion & 1905 & $\%$ & 1914 & $\%$ & 1916 & $\%$ & $\begin{array}{l}\text { Males, European } \\
\text { Russia, } 1897\end{array}$ & $\%$ \\
\hline Orthodox & 96 & 92 & 85 & 89 & 116 & 92 & $37,310,642$ & 82 \\
\hline Lutheran & 6 & 6 & 9 & 9 & 6 & 5 & $1,488,869$ & 3 \\
\hline Roman Catholic & 2 & 2 & 1 & 1 & 4 & 3 & $2,175,353$ & 5 \\
\hline All other Christian & 0 & 0 & 0 & 0 & 0 & 0 & 888,620 & 2 \\
\hline Non-Christian & 0 & 0 & 0 & 0 & 0 & 0 & $3,734,577$ & \\
\hline TotaL & 104 & 100 & 95 & 99 & 126 & 100 & $45,598,061$ & 100 \\
\hline
\end{tabular}

The material summarized in the following tables was taken from three volumes of the Spisok vysshikh chinov (List of Higher Ranks), the annual register of higher civil servants published by the Russian government for its internal use only. The registers bear the publication dates 1905,1914 , and $1916 .^{3}$ It may therefore be assumed that the tables represent the state of affairs at the upper reaches of MVD administration at the following points in time: (1) before the implementation of the Manifesto of October 1905, (2) at the conclusion of the interwar, interrevolutionary period, but before the outbreak of World War I, and (3) at the end of approximately two years of world war. ${ }^{4}$

As its name implies, the List of Higher Ranks deals with those persons -and only those persons-holding one or another of the highest service ranks in the state bureaucracy..$^{5}$ To be included, the person had to be holding an active-duty appointment with an agency of the central administration of the Ministry. ${ }^{6}$ Although it is not accurate to say that the level of a civil servant's official position or office was directly related to his service rank, the tenure of higher positions in the Ministry was limited to persons holding one of the highest ranks. These civil servants may thus be thought of as "managers," "executives," or "senior counselors" in the MVD bureaucracy. Finally, it should be noted that since each List contains information on all righer-ranking active duty officials, the information summarized in the following tables is not drawn from a sample but includes 100 percent of the higher-ranking, executive

3. Spisok vysshikh chinov tsentral'nykh ustanovlenii Ministerstva Vnutrennikh Del, part 1 (St. Petersburg, 1905, 1914, and 1916). For 1914 and 1916 specific dates are given-May 7 and October 10 respectively.

4. It is perhaps unnecessary to note that this selection of "events" in the society at large is done arbitrarily and merely to place the MVD data in its most obvious context. Any attempt to explain variance in the data by reference to these events alone risks a great deal.

5. No one from the groups we are concerned with held the highest rank of kantsler. The relevant ranks are 2 through 5: deistvitel'nyi tainyi sovetnik, tainyi sovetnik, deistvitel'nyi statskii sovetnik, and statskii sovetnik. For further explanation see L. M. Rogovin, comp., Ustav o sluzhbe (Petrograd, 1915) especially part 2, pp. 119-215.

6. Part 2 of the Spisok vysshikh chinov typically dealt with provincial incumbents. Different editions were designed to serve different purposes. Cf., for example, Spisok lits sluzhashchikh po vedomstvn Ministerstvo Vnutrennikh Del, which includes lower ranks. 
population of the MVD-105, 95, and 126 persons in 1905, 1914, and 1916 respectively.

The social characteristics we are dealing with may be grouped into career and demographic categories, and include the following discrete classes of information:

Demographic Variables

Date of birth

Religious affiliation

Education: $(a)$ level attained,

(b) subject specialization

Legal-hereditary class (that is, passport or legal designation)

Landholdings

Marital status

Wife's legal-hereditary class

Wife's landholdings

\section{Career Variables}

Date of entry into state service

Service rank

Salary

Office of employment

(that is, agency)

Although the significance of some of these categories is obvious, others require explanation. "Religious affiliation," as it is used in the foregoing list and in table 2 is a legal designation. It does not necessarily convey any information on belief, religious practice, or (in the case of Lutherans and Roman Catholics) ethnicity. The information on education is based on the name of the last educational institution attended. Thus assessments about "level attained" and "subject specialization"-of central importance to table 5-were interpolated from other work on nineteenth and twentieth-century Russian education, ${ }^{7}$ and may, for example, discriminate inaccurately between one person who attended a university and another who attended a higher military school, though they studied identical subjects. The concept of class (soslovie), integral to the government documents at our disposal, is both an aid and a hindrance to our task. It is a legal-hereditary designation rather than a sociological or economic one. In practice, we are able to distinguish the following legal classes of origin from late prerevolutionary demographic sources: (1) gentry (hereditary and personal), (2) clergy, (3) hereditary honored citizens, (4) burghers (five subdivisions), and (5) peasantry. ${ }^{8}$ In addition, the documents from which the MVD data have been taken specify nonnobles whose fathers were ranking officials in the civil service or officers in the Russian armed forces. Unfortunately in the same documents the members of the hereditary nobility or holders of hereditary honored citizenship whose fathers were officials or

7. In particular, William H. E. Johnson, Russia's Educational Heritage (Pittsburgh, 1950 ; reprint, New York, 1969), chaps. 5 and, especially, 8. See also tables 32 and 33 in the same work.

8. For a more extensive discussion see N. D. Lazarevsky, "Soslovie," in Entsiklopedicheskii Slovar' (St. Petersburg, 1900), 30:911-13. 
officers are simply called "hereditary nobility," which makes it impossible to say what part of the whole contingent of MVD managers came from families where bureaucratic employment was common. It is equally unfortunate that these figures can be seen only in the context of the one general census-that of 1897. Within those limits, the picture that emerges is reflected in table 1.

Three characteristics of the data on MVD class structure from 1905 to 1916 are especially interesting. First, class representation in the higher offices and ranks of the Ministry was roughly the inverse of the distribution of class for the entire population of European Russia. In the Russian Empire the state of affairs was such that most of the highest ranking civil servants in this important ministry were from a tiny proportion of the whole population (the hereditary nobility). The group therefore had an extraordinary advantage in competition with other classes for such prestigious positions. Second, the data show that the dominance of nobility was declining: nobility constituted 83 percent of the higher MVD civil servants in 1905, but only 75 percent in 1916. Third, landholding was a significant characteristic of the nobility (but only of the nobility) throughout the period under question; it was not, however, a characteristic of much more than a third of this group. If we accept landholding as one indicator of financial independence in prerevolutionary Russia, then the majority of the MVD higher civil servants did not conform to the image of the gentleman bureaucrat. ${ }^{\circ}$ This conclusion is reinforced by salary levels (about 6,000 rubles, on the average, for the entire group) and the average length of career (thirty-four, thirty-one, and twenty-eight years for 1905, 1914, and 1916 respectively).

Table 2 shows the distribution of religious affiliation among MVD higher civil servants between 1905 and 1916 and also draws on the best information we have available for comparing them with the whole population-the 1897 census. Here, instead of the inversion of distributions that we saw in table 1 , we have a reasonably high conformity among comparable cells in the four categories-with one exception. The MVD higher civil service was exclusively Christian; indeed, its highest officials were drawn only from the three traditionally dominant Christian religions in the Russian Empire, and excluded both small Christian sects and large non-Christian religions such as Islam and Judaism. Religious affiliation, defined in terms of dominant traditions in the society, would seem to have been a distinctive part of a cultural pattern to which members of the MVD higher civil service conformed, irrespective of the year we choose for an example between 1905 and 1916.10

9. Taken indiscriminately, of course, the attribute of landholding is not a reliable index of "financial independence." Intervening circumstances such as indebtedness, the market or productive value of the landholding, and the amount of land were important.

10. The percentage variances in table $2-$ as well as in the other tables-must be interpreted with care, since in some instances they involve very few people. 
Table 4. Agencies of the Central MVD Grouped According to Apparent Specialization, 1905-16

General Administration and

Policy-Making Agencies:

Office of the Minister and Deputy Ministers

Council of the Minister

Chancellery of the Ministry

Officials Specially Assigned or Established

Department of Clergy Affairs for Foreign Confessions (no listings for 1905)

Land Division

Conference on Affairs Related to Food Distribution (no listings for 1914)

Main Administration for Affairs of Local Economy

Council for Affairs of Local Economy (no listings for 1914)

Main Administration for Posts and Telegraph

Migration Administration (no listings for 1914 and 1916)

Police and Control Agencies:

Department of Police

Administration for Military Responsibility

Separate Corps of Gendarmes
Information and Education Agencies:

Council of the Main Administration for Affairs of the Press

Main Administration for Affairs of the Press (no listings for 1905 and 1916)

Editorial Offices of the Government Messenger (no listings for 1914 and 1916)

Asylum (Orphanage) of Prince Peter Georgievich Oldenburg

Professional and Technical Management

Divisions:

Electro-technical Institute

Medical Council

Administration of Main Medical Inspector

Imperial Institute of Experimental Medicine (no listings for 1905)

Veterinary Committee

Veterinary Administration

Statistical Council

Central Statistical Committee

Technical Building Committee

Institute of Civil Engineers

Technically Oriented Interministerial Committees (no listings for 1905 and 1916)

A brief look at patterns of marital selection substantiates the conclusions about conformity to a prevailing cultural pattern. The difficulty here is that the data on marital status do not permit us to distinguish wives by hereditarylegal class as we have the members of the MVD administration. Instead it is necessary to combine some categories. The result, however, clearly reaffirms the class distinctions which are already evident for the civil servants themselves. Of the 1905 group, for example, 88 percent of civil servants' wives were from one of the noble or state official categories; the comparable figure for the officials themselves is 91 percent. The figures for 1914 are 96 percent for wives and 87 percent for officials. Landholding among wives of MVD officials was considerably less common than it was among their husbands, which reflects a similar tendency throughout the society. Of course this is consistent with the earlier observation that these officials apparently needed their salaries, because they probably had no alternative sources of income.

Endowed with such social characteristics as we have seen, how did MVD higher civil servants prepare themselves for their careers? The data confirm, on the whole, that the persons who occupied managerial positions in the MVD 
were relatively highly educated, in the sense that they often were graduates of universities or technical-professional institutes similar to those found in Germany, France, or the United States at the time. There was, in other words, no bias against exceptionally high formal education, such as one may find in many so-called prebureaucratic administrations. Evidence for this view is initially summarized in table 3 , where a comparison can be made between MVD higher civil servants and two other comparable segments of Russian society at the time-upper-class males over twenty and all European Russian males over twenty.

We may also ask whether there is any noticeable relation between the kind of education an MVD higher civil servant acquired and his apparent activity in the civil service. Table 4 suggests a broad range of functions for MVD agencies by showing them all listed together under four categories. The criteria for this division were the title of the agency and the description of its function and objectives which appeared in the St. Petersburg city registers. ${ }^{11}$ When no clear functional specialization emerged, the agency was assigned to the "administrative policy-making" category. Agencies whose tasks included education but not research or administration were assigned to "information and education." Those with a research orientation, even if they also included teaching, were assigned to the "professional and technical" category. It will be noted that the existence of certain agencies in the "professional and technical" category-as well as some others-shows a clear organizational response to technological and economic change in the society.

Is there any noticeable relation between the kind and amount of education an MVD executive had acquired and his apparent activity as a higher civil servant? Table 5 suggests a number of possible answers to that question. First, the characteristic of a higher education (either in a university or an advanced professional school) was rather evenly distributed throughout the upper ranks of the Ministry ("information and education" in 1905 and "police" in 1916 are the only areas in which the rate falls below 70 percent ${ }^{12}$ ). Second, those agencies with consistently the highest proportion of university graduates were the "professional and technical" ones. In addition, inspection of individual careers of officeholders in these agencies shows considerable professional experience in educational and research institutes outside the MVD. These are not surprising facts unless one considers that a quite plausible alternative would be one in which generalist administrators dominated the agencies, and

11. See, for example, the introductory material in Ves' Peterburg na 1904 god: Adresnaia $i$ spravochnaia kniga g. S.-Peterburga (St. Petersburg, 1904).

12. Again, it should be noted that large percentage variances reflect only a small variation in numbers of officials. 


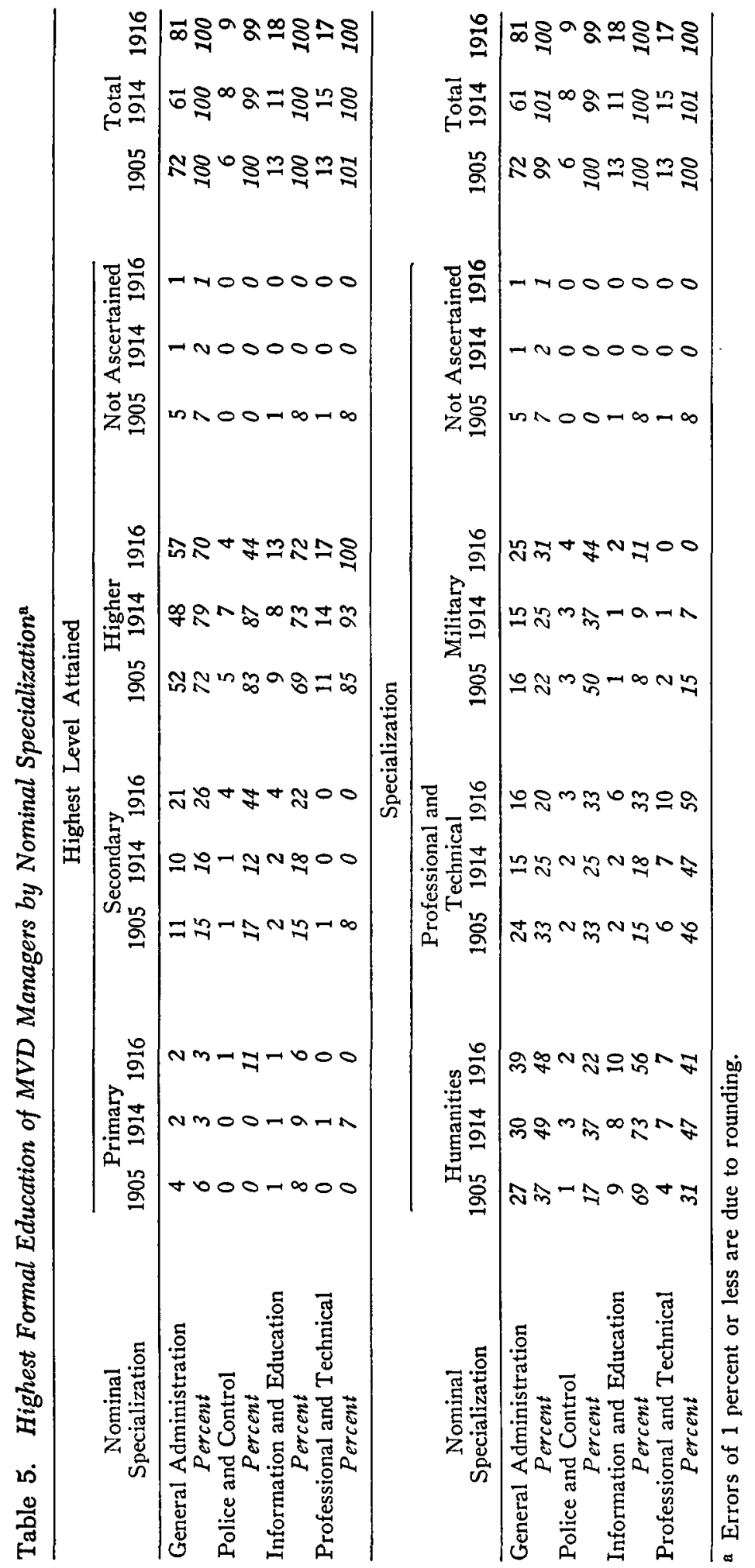


Table 6. Age, Career, and Salary Characteristics of MVD Higher Civil Servants, 1905-16

\begin{tabular}{|c|c|c|c|c|c|c|c|c|c|}
\hline \multirow{2}{*}{$\begin{array}{c}\text { Agency } \\
\text { Specialization }\end{array}$} & \multicolumn{3}{|c|}{ Mean Year of Birth } & \multicolumn{3}{|c|}{$\begin{array}{c}\text { Mean Year of } \\
\text { Entry into Service }\end{array}$} & \multicolumn{3}{|c|}{$\begin{array}{l}\text { Mean Salary } \\
\text { (in rubles) }\end{array}$} \\
\hline & $\overline{1905}$ & 1914 & 1916 & 1905 & 1914 & 1916 & 1905 & 1914 & 1916 \\
\hline $\begin{array}{l}\text { General Administration } \\
\text { and Policy-Making }\end{array}$ & 1849 & 1861 & 1866 & 1870 & 1882 & 1888 & 6,653 & 5,957 & 5,493 \\
\hline $\begin{array}{l}\text { Police and Control } \\
\text { Information and }\end{array}$ & 1859 & 1863 & 1863 & 1879 & 1887 & 1887 & 5,968 & 5,200 & 6,475 \\
\hline $\begin{array}{l}\text { Education } \\
\text { Professional and }\end{array}$ & 1848 & 1859 & 1863 & 1870 & 1881 & 1886 & 4,546 & 3,727 & 3,381 \\
\hline Technical & 1851 & 1859 & 1862 & 1875 & 1882 & 1886 & 7,750 & 7,606 & 6,603 \\
\hline
\end{tabular}

experts were merely on tap. Third, there appears to be an overall connection between the kind (as distinct from the amount) of educational experience these men had and the kinds of positions they were holding in 1905, 1914, and 1916. In my opinion, however, the connection is not strong or regular enough to warrant drawing conclusions about the orientation, breadth, or narrowness of careers.

Finally, we may ask whether other factors appear to distinguish higher civil servants in one area of specialization from another. Table 6 compares the agencies in light of three sets of characteristics that often have a bearing on the status of persons in formal bureaucracies: age, length of career, and salary. The figures on date of birth and entry into state service are interesting, because they suggest that a certain threshold of maturity and organizational seniority had to be passed in order to secure high rank and managerial status, whatever the area of specialization. Virtually every higher civil servant in this study entered service between the ages of nineteen and twenty-three. The salary figures, besides displaying a downward trend, show a clear distinction between specializations. Even though the highest individual salaries in the Ministry (26,000 to 15,000 rubles for the minister and his deputies) were to be found in the "general administration" category, the highest mean figures were consistently those for the "professional and technical" specializations. Moreover, although officials in "information and education" tended to be the oldest and have the longest careers, the salaries they drew were consistently lower than those in other areas.

Taken together, the data on MVD higher civil servants and the governmental organization which they served suggest a homogeneous, elite group drawn from a tiny minority of the whole population and operating within a functionally diverse bureaucratic system. The data that deal specifically with education and salary indicate that-at least in the early twentieth century-a certain amount of educational specialization occurred as these men prepared for their careers. Once the high rank and the managerial status were attained, 
the skill and experience characteristic of the "professional and technical" area of specialization could command greater monetary rewards than similar qualifications in nonprofessional specializations. Furthermore, the existence of agencies for administration of telegraph service and research in sophisticated scientific areas suggests that the Ministry, as a structural whole, underwent at least some significant change, probably in response to modernization elsewhere in the society. Nevertheless, so far as the social characteristics of the bureaucrats are concerned, the picture that emerges is similar to the one drawn by Pintner from data for the central Russian civil service between 1800 and $1850 .{ }^{13}$ Social origins of officials, the tendency for officials to be lifelong professionals, and the role of education are all similar. In view of the accumulation of changes in Russian society between 1850 and 1917, such apparent stability within the central civil service inevitably raises questions concerning the responsiveness of the Ministry to external change. ${ }^{14}$

13. Walter M. Pintner, "The Social Characteristics of the Early Nineteenth-Century Russian Bureaucracy," Slavic Review, 29, no. 3 (September 1970): 429-43, especially table 9 and pp. $436 \mathrm{ff}$.

14. The role of education in "modernizing" the values and technical competence of the higher civil servants is probably paramount here. Additional research on the content of higher formal education and the specific processes whereby individuals were "selected into" the educational system and thence into the bureaucracy seems essential. 